\title{
S100 Calcium Binding Protein A8 Measurement
}

National Cancer Institute

\section{Source}

National Cancer Institute. S100 Calcium Binding Protein A8 Measurement. NCI

Thesaurus. Code C154730.

The determination of the amount of $\mathrm{S} 100$ calcium binding protein $\mathrm{A} 8$ present in a sample. 